\title{
The Implementation of Partial Roya after Regulation of Minister of Agrarian \& Spatial Planning
}

\author{
Muhammad Iqbal al Hakiem*), Sri Endah Wahyuningsih*) and Dahniarti \\ Hasana***) \\ *) Faculty of Law, Universitas Islam Sultan Agung (UNISSULA) Semarang, E-mail: \\ hakimiqbal42@gmail.com \\ ${ }^{* *)}$ Faculty of Law, Sultan Agung Islamic University (UNISSULA) Semarang, E-mail: \\ endah.w@unissula.ac.id \\ $\left.{ }^{* * *}\right)$ Faculty of Law, Universitas Islam Sultan Agung (UNISSULA) Semarang, E-mail: \\ dahniarti@unissula.ac.id
}

Abstract. This study aims to determine and analyze the authority of a Notary/PPAT in the implementation of partial roya after the enactment of the Regulation of the Minister of Agrarian Affairs and Spatial Planning/Head of the National Land Agency of the Republic of Indonesia No. 5 of 2020 concerning Electronically Integrated Mortgage Services. This research method uses a sociological juridical approach with descriptive research specifications. Data sources and data collection methods used primary and secondary data which were analyzed qualitatively. The results of this study indicate that the authority of a Notary/PPAT has an important role in the implementation of partial roya in the city of Semarang. The authority of the Notary/PPAT is the making of a credit agreement deed with a partial roya agreement, a roya concession deed if the mortgage certificate is lost, creation and registration of APHT with partial roya agreement and submission of roya application against conventional Mortgage Rights. Notaries/PPATs in carrying out their authority must comply with the applicable laws and regulations to ensure legal certainty. The implementation of partial roya at BPN Semarang City is currently divided into two, namely conventionally and electronically. The implementation of partial roya at BPN Semarang can be done without the need for prior agreement in the APHT. Partial roya on part of the result of splitting the parent certificate which is encumbered with Mortgage Rights can be made at BPN Semarang City on condition that it must be agreed upon by the creditor and debtor. The conclusion is implementation of partial roya using the electronic Mortgage system provides more benefits in terms of convenience and time efficiency.

Keywords : Mortgage; Partial; Regulation; Right; Roya. 


\section{Introduction}

Mortgage Rights are Guarantee Rights that are imposed on land rights as referred to in Act No. 5 of 1960 concerning Basic Regulations on Agrarian Principles, including or not including other objects which are an integral part of the land for the settlement of certain debts, which provide position that is prioritized for certain creditors over other creditors. Mortgage registration is preceded by a credit agreement. The form of guarantee agreement in practice is in written form. This cannot be separated from the procedure for loading guarantees on an object. ${ }^{1}$ Credit agreements can be made either in the form of a deed which is the authority of a Notary, or in the form of an underhand agreement, which is then used as the basis for making the Deed of Granting Mortgage which is the authority of the PPAT (hereinafter referred to as APHT).

Debtors who have paid off their debts can take back the certificate as collateral which is then written off the Mortgage Rights or roya. The debtor who has pledged several certificates can perform partial roya by paying off part of his debt which is equivalent to the certificate to be roya. Partial roya is the deletion of Mortgage on some certificates that are the object of the Mortgage, so that some of the certificates are separated from the Mortgage and then the Mortgage only burdens the rest of the object to guarantee the repayment of the debt. Partial Roya is an exception to the nature of Mortgage which cannot be divided. ${ }^{2}$

Problems that can occur in the implementation of partial roya are when the land certificate is used as debt collateral and is encumbered with mortgage rights, then at a certain time the debtor makes a split/separation of the parent land certificate into several certificates. When the land resulting from the split/separation wants to be sold, the developer realizes the need for a partial roya on the certificate of the land that he wants to sell.

The split/separation of the parent certificate that is encumbered with the Mortgage Rights can be carried out with the relevant burden not always having to be removed. In the event that the right is encumbered with a mortgage, the mortgage in question continues to burden the areas resulting from the split. The agreement on partial roya in APHT against the above problems is sometimes not

\footnotetext{
${ }^{1}$ Malik, Djatmika., Limbong, Mangirim., \& Wahyuningsih, Sri Endah. (2018). “Legal Protection for Debtors in Selling Of Immovable Guaranteed Objects Below The Market Price In Indonesian Positive Law". In Jurnal Akta. Vol. 5, No. 2, June 2018, p. 355.

${ }^{2}$ Kinanti, Karenandrie Pradnya., Suharto, R., \& Adhi, Yuli Prasetyo. (2012). "Roya Parsial terhadap Jaminan Hak Tanggungan dalam Praktek di Kantor Pertanahan Kota Semarang" in Diponegoro Law Review, Volume 1 No 4, p. 2.
} 
carried out because the object of collateral does not yet exist at the time of making APHT, making it difficult for debtors and creditors to perform partial roya.

The results of research by Ida Bagus and I Wayan in the Journal of Legal Sciences Kertha Semaya Vol. 8 (2020), Partial Roya can be carried out on part of the land resulting from the split from the parent certificate which is burdened with Mortgage Rights. This is based on the provisions of Article 124 paragraph (1) and paragraph (2) of the Regulation of the Minister of Agrarian Affairs/Head of the National Land Agency No. 3 of 1997 concerning Provisions for the Implementation of Government Regulation No. 24 of 1997 concerning Land Registration. ${ }^{3}$

The Roya service since the enactment of the Regulation of the Minister of Agrarian and Spatial Planning/Head of the National Land Agency of the Republic of Indonesia No. 5 of 2020 concerning Electronic Integrated Mortgage Services (hereinafter referred to as PERMEN HT-el), is carried out with an electronic system. Roya's service with an electronic system cannot be said to be optimal because it has several limitations. The limitation in question is that Roya's service with an electronic system can only be performed on an electronic Mortgage Certificate, and Roya's service for certificates resulting from splitting/separation from the parent certificate that is encumbered with Mortgage Rights has not been regulated in the electronic system ${ }^{4}$.

Starting from the provisions of Article 124 paragraph (1) and paragraph (2) of the Regulation of the Minister of Agrarian Affairs/Head of the National Land Agency No. 3 of 1997 which is contrary to the provisions of Article 2 paragraph (1) and paragraph (2) of Act No. 4 of 1996 concerning Mortgage rights, as well as the limitations of Roya services with an electronic system, it is important to conduct research related to the implementation of partial roya after the enactment of the Regulation of the Minister of Agrarian and Spatial Planning/Head of the National Land Agency of the Republic of Indonesia No. 5 of 2020 concerning Electronically Integrated Mortgage Services in Semarang City.

\footnotetext{
${ }^{3}$ Putra, Ida Bagus Jaya Maha., \& Wiryana, I Wayan. (2020). “Roya Parsial Terhadap Hak Tanggungan Bagi Pengembang Yang Menerima Kredit Konstruksi Di Bpr Lestari”. in Jurnal IImu Hukum Kertha Semaya, Vol. 8, No. 2, January 2020, p. 110.

${ }^{4}$ Deen, Thaufiq., Ong Argo Victoria \& Sumain. (2018). Public Notary Services In Malaysia. JURNAL AKTA: Vol. 5, No. 4, 1017-1026. Retrieved from http://jurnal.unissula.ac.id/index.php/akta/article/view/4135
} 


\section{Research Methods}

This research method uses a sociological juridical approach. The sociological juridical approach was used because this research was conducted to obtain legal knowledge empirically by going directly to the object, namely the implementation of Partial roya since the enactment of Ministerial Regulation of ATR/BPN No. 5 of 2020 in Semarang City. The specification of this research is descriptive by presenting factual information or data in a systematic and accurate manner regarding the implementation of Partial roya since the enactment of Ministerial Regulation of ATR/BPN No. 5 of 2020 in Semarang City. Sources of data and data collection methods using primary data obtained by means of interviews with resource persons who are considered to understand the research topic and secondary data obtained by reviewing the literature related to the research topic.

\section{Results and Discussion}

3.1. Authority of the Notary/PPAT in the Implementation of Partial Roya after the Enactment of the Regulation of the Minister of Agrarian and Spatial Planning/Head of the National Land Agency of the Republic of Indonesia No. 5 of 2020 concerning Electronic Integrated Mortgage Services

The implementation of partial roya is the authority of the National Land Agency (hereinafter referred to as BPN). The authority is stated in Article 22 paragraph (8) UUHT. Nevertheless, the authority of the Notary/PPAT has a role so that the implementation of the partial roya can run well. The Notary's authority related to the implementation of the partial roya is the making of a credit agreement deed and a roya concession deed. PPAT's authority related to the implementation of partial roya is the creation and registration of APHT by PPAT with a partial roya agreement in it and the submission of a roya application.

The credit agreement deed is made as a form of security so that the parties do not break their promises (default). The credit agreement deed is an authentic deed that can be used as perfect evidence. Article 1870 of the Civil Code regulates the strength of proof of an authentic deed which states that an authentic deed provides between the parties and their heirs or persons who have rights from them, a perfect proof of what is contained therein. ${ }^{5}$ The agreement regarding partial roya needs to be included in the credit agreement deed if it is desired as the basis for making APHT by PPAT.

\footnotetext{
${ }^{5}$ Article 1870 of the Civil Law Act.
} 
A deed of consent roya is a statement of agreement to do roya which is usually used to replace a lost mortgage certificate. Roya consent deed is a deed made before a Notary at the request of the debtor and/or creditor containing a statement that the Mortgage Certificate which is under his control has been lost, where the Mortgage Certificate is a requirement for debtors who have paid off their debts to make roya.

Consensus roya deed has different legal force from Mortgage certificate. The roya consent deed only serves as a formal requirement and administrative orderly requirement as a substitute for a mortgage certificate in the case of the implementation of the roya. Consensus deed does not have the executive power as contained in the Mortgage certificate. ${ }^{6}$

APHT is an authentic deed made by PPAT based on the information of the parties (creditors and debtors). APHT regulates the terms and conditions regarding the granting of Mortgage Rights from debtors to creditors related to land rights certificates which are used as collateral for debts with Mortgage Rights.

APHT must include the name and identity of the holder and giver of the Mortgage, the domicile of the parties, the debt or debts that are guaranteed, the value of the mortgage, and a clear description of the object of the Mortgage. APHT may also contain other promises agreed by the parties. The object of the Mortgage consists of several rights to land and if in the future a partial roya is desired, it is necessary to agree in the relevant APHT that the repayment of the guaranteed debt can be carried out in installments with the amount equal to the value of each land right which constitutes a mortgage. Part of the object of the Mortgage, which will be released from the Mortgage, so that then the Mortgage will only burden the rest of the object of the Mortgage to guarantee the remaining outstanding debt.

APHT that has been made must be registered by PPAT to BPN. APHT registration after the enactment of the HT-el PERMEN is carried out electronically using the PPAT account and the submission of an application for roya by PPAT can only be done against conventional Mortgage Rights. The submission of a roya application by PPAT is carried out electronically through the PPAT online counter on the website: https://mitra.atrbpn.go.id/.

${ }^{6}$ Valentini, Ni Putu Erna., \& Yogantara, Pande. (2021) “Pencoretan Hak Tanggungan dengan Akta Konsen Roya”. In Jurnal Hukum Kenotariatan, Vol. 6. No. 1, March 2021, p. 16 
3.2. Analysis of Legal Certainty on the Authority of a Notary/PPAT in the Implementation of Partial Roya after the Enactment of the Regulation of the Minister of Agrarian Affairs and Spatial Planning/Head of the National Land Agency of the Republic of Indonesia No. 5 of 2020 concerning Electronic Integrated Mortgage Services

Gustav Radbruch put forward 4 (four) basic things related to the meaning of legal certainty, namely that the law is positive, based on facts, these facts must be formulated in a clear way, and positive law should not be easily changed. Based on this opinion, it can be concluded that normative legal certainty is when a statutory regulation is made and promulgated with certainty which regulates clearly and logically, so that it will not cause doubt due to the existence of multiple interpretations that can clash or cause conflicting norms. The general rules in the Act serve as guidelines for individuals in behaving in society, both in relation to fellow individuals and in relation to society. These rules become a barrier for society in burdening or taking action against individuals. The existence of these rules and their implementation will lead to legal certainty. ${ }^{7}$

The term bank credit agreement is found in Government instructions, which are addressed to the public or bank customers. Banks are instructed that in providing credit in any form, they must use a "credit agreement". The legal basis for the existence of a credit agreement in banking credit is contained in Article 1 paragraph (11) and paragraph (12) of Act No. 10 of 1998 concerning Banking. The article states that credit is given based on an agreement or loan agreement between the bank and other parties. ${ }^{8}$

The legal basis for the roya concession deed as one of the requirements for conducting roya by the BPN office is stated in the Regulation of the Head of the National Land Agency of the Republic of Indonesia No. 1 of 2010 concerning Service Standards and Land Regulations dated January 25, 2010 in attachment II of the section on the abolition of mortgage rights or roya with the following requirements: following:

a. Application form that has been filled out and signed by the applicant or his/her proxy on sufficient stamp duty.

b. Power of Attorney if authorized.

\footnotetext{
${ }^{7}$ Marzuki, Peter Mahmud. (2008). Pengantar Ilmu Hukum. Jakarta: Kencana, p. 158.

${ }^{8}$ Kamelia, Mariah., \& Mashdurohatun, Anis. (2017). “Peran Notaris Dalam Pembuatan Akta Perjanjian Kredit Dalam Perspektif Hukum Positif dan Hukum Islam”. In Jurnal Akta, Vol. 4, No. 4, December 2017, p. 579.
} 
c. Photocopy of applicant's identity (KTP and KK) and power of attorney if authorized, which has been matched with the original by the counter officer.

d. Photocopy of Deed of Establishment and Legalization of Legal Entity which has been matched with the original by the counter officer, for legal entities.

e. Land certificate and Mortgage certificate and or royalty concession if the mortgage certificate is lost.

f. Letter of roya/debt statement/debt settlement from creditor.

g. Photocopy of KTP of the HT giver (debtor), HT recipient (creditor) and or their proxy which has been matched with the original by the counter officer.

The credit agreement deed and the agreement deed are partij deed. Partij deed is a deed made by a notary at the request of the parties, so that the notary records or writes down everything explained by the parties before the notary into the deed. ${ }^{9}$ So even though it is a notary who makes the deed, the initiative comes from the interested parties. ${ }^{10}$

The authority of a Notary in making a deed of credit agreement and a deed of concession agreement is implied in Article 15 paragraph (1) of the UUJN which states that a Notary has the authority to make an authentic deed regarding all acts, agreements, and stipulations required by laws and regulations and/or desired by the have an interest to be stated in an authentic deed, guarantee the certainty of the date of making the deed, keep the deed, provide grosse, copies and quotations of the deed, all of which are as long as the making of the deed is not assigned or excluded to other officials or other people stipulated by law.

The credit agreement deed and the agreement deed that guarantee legal certainty must be made by a Notary based on the provisions and obligations contained in the laws and regulations as contained in Article 1320 of the Civil Code regarding the legal terms of the agreement, Article 16 of the UUJN regarding the obligations of a Notary related to the deed, and Article 38 UUJN regarding the structure of the deed.

PPAT's authority in making APHT is contained in several laws and regulations, namely:

\footnotetext{
${ }^{9}$ Adjie, Habib. (2011). Hukum Notaris Indonesia, Tafsir Tematik Terhadap UU No. 30 Tahun 2004 tentang Jabatan Notaris. Bandung: Refika Aditama, p. 45.

${ }^{10}$ Ngadino. (2019). Ketentuan Umum Tata Cara Pembuatan dan Pengisian Akta PPAT. Semarang: Universitas PGRI Semarang Press, p. 95.
} 
a. Act No. 4 of 1996 concerning Mortgage on Land and Objects Related to Land.

b. Government Regulation of the Republic of Indonesia No. 37 of 1998 concerning Regulations on the Position of Land Deed Maker Officials.

c. Regulation of the State Minister of Agrarian Affairs/Head of National Land Agency No. 3 of 1997 concerning Provisions for Implementation of Government Regulation No. 24 of 1997 concerning Land Registration in conjunction with Regulation of the Head of the National Land Agency No. 8 of 2012 concerning Amendments to Regulation of the State Minister of Agrarian Affairs/Head of National Land Agency No. 3 of 1997 concerning Provisions for Implementation of Government Regulation No. 24 of 1997 concerning Land Registration.

d. Regulation of the Minister of Agrarian and Spatial Planning/Head of the National Land Agency of the Republic of Indonesia No. 5 of 2020 concerning Electronic Integrated Mortgage Services.

APHT which guarantees legal certainty must be made PPAT based on the provisions and obligations contained in the legislation, namely Article 1320 of the Civil Code regarding the legal terms of the agreement, Article 11 of the UUHT regarding the contents of the APHT content, Article 2 paragraph (2) UUHT regarding partial roya agreements in APHT, Attachment 6 Regulation of the Head of the National Land Agency No. 8 of 2012 concerning Amendments to the Regulation of the State Minister of Agrarian Affairs/Head of the National Land Agency No. 3 of 1997 concerning Provisions for the Implementation of Government Regulation No. 24 of 1997 concerning Land Registration regarding the APHT structure, Article 21 - Article 26 of the Government Regulation of the Republic of Indonesia No. 37 of 1998 concerning the Regulation of the Position of the Land Deed Making Officer regarding the PPAT obligations related to the deed he made, and Article 10 paragraph (1) of the PERMEN HT-el regarding the registration of APHT with the electronic Mortgage system.

3.3. Implementation of Partial Roya after the enactment of the Regulation of the Minister of Agrarian Affairs and Spatial Planning/Head of the National Land Agency of the Republic of Indonesia No. 5 of 2020 concerning Electronically Integrated Mortgage Services in Semarang City

The implementation of partial roya after the enactment of PERMEN HT-el in Semarang City is divided into two, namely conventionally and electronically. Partial roya is conventionally made to a mortgage certificate in conventional form, while a partial roya can be done electronically to an electronic mortgage certificate. Conventional Mortgage Certificates cannot be partially redeemed 
electronically because the current electronic Mortgage System has not been able to accommodate this.

BPN Semarang City allows partial roya without the need for an agreement in the APHT as long as the creditor and debtor agree to it. However, the Semarang City National Land Agency also emphasized that it is better to make a partial roya agreement in advance in the APHT so as not to harm the creditor and to ensure the security of the creditor against the object that is burdened with the Mortgage. ${ }^{11}$

A conventional partial roya application can be submitted by the Mortgage holder, the Mortgage giver, the concerned land right holder, or can be authorized to PPAT. Applications for conventional partial roya can be done independently by visiting the Semarang City National Land Agency by bringing the necessary requirements. A partial roya application authorized to PPAT can be made by providing a power of attorney to PPAT along with the required requirements, then PPAT will submit a partial roya application through the PPAT online counter electronically. The requirements needed in filing a partial roya are:

a. The application form that has been filled out and signed by the applicant or his/her proxy on sufficient stamp duty.

b. Power of Attorney if authorized.

c. Photocopy of applicant's identity (KTP, KK) and power of attorney if authorized, which has been matched with the original by the counter officer.

d. Photocopy of Deed of Establishment and Legalization of Legal Entity which has been matched with the original by the counter officer, for legal entities

e. Land certificate and Mortgage Certificate and/or roya concession if the Mortgage certificate is lost.

f. Letter of Roya/Certificate of Settlement/Debt Settlement from Creditors.

The required documents that have been submitted will be matched by the Semarang City BPN counter officer, then the applicant will be given a PNBP bill for the partial roya management fee. Furthermore, the Semarang City BPN will cross out the Mortgage Rights and write down the notes on the land book, the Mortgage certificate, and the land title certificate. The certificates taken after the roya is completed are the certificate of land rights that have been roya and the

\footnotetext{
11 Interview with Heri Apriyanto, SH as Coordinator of Substance Group for Land and Space Registration, Communal Land and Institutional Relations in Semarang on Tuesday, 22 June 2021, 09.00 .
} 
certificate of mortgage that has been partially roya. The Mortgage Certificate is then handed back to the creditor as the Mortgage holder and the land title certificate can be kept by the land rights holder.

The implementation of partial roya electronically is carried out using an electronic mortgage system. The electronic Mortgage System in Semarang City came into effect in its entirety on July $8,2020 .{ }^{12} \mathrm{~A}$ partial roya application to the Semarang City BPN can only be made through the creditor's account as the holder of Mortgage Rights. Electronic partial roya applications for electronic Mortgages cannot be authorized to PPAT. This is contained in Article 22 letter $b$ of the PERMEN HT-el where registered users are prohibited from giving usernames and/or passwords to other parties that cause access to information to be opened.

The division of land rights that are encumbered with Mortgage Rights which is then carried out a partial roya on some of the certificates resulting from the split can run well at the Semarang City National Land Agency. The requirements needed to carry out the settlement are the approval of the creditor to do the split and the requirements in the Regulation of the Head of the National Land Agency of the Republic of Indonesia No. 1 of 2010 concerning Service Standards and Land Regulations, namely:

a. The application form that has been filled out and signed by the applicant or his/her proxy on sufficient stamp duty.

b. Power of Attorney if authorized.

c. Photocopy of applicant's identity (KTP, KK) and power of attorney if authorized, which has been matched with the original by the counter officer.

d. Original certificate.

e. Permit for Change of Land Use, if there is a change in land use.

f. Attach proof of SSP/PPh in accordance with the provisions.

g. The plot of the plot of the Land Office.

The results of the splitting of land rights will issue a new No., NIB, letter of measurement, land book, and certificate of land rights with the same legal status as the certificate of origin, while the old one is no longer valid. Mortgage records which originally burdened the parent land title certificate will be recorded in the respective land books and new certificates. All certificates resulting from the separation will also be recorded on the certificate of Mortgage. The partial roya

\footnotetext{
12 Ibid.
} 
application can be done conventionally or electronically depending on the type of mortgage certificate. ${ }^{13}$

The problem that arises from the partial roya on the results of the division of land that is burdened with Mortgage Rights is that the object is born after the APHT is made and registered. The solution to this problem is to add a partial roya clause in Article 2 of the APHT standard form which reads:

In the event that the Mortgage Object is then divided so that the Mortgage encumbers several land rights, the Debtor can repay the debt guaranteed by the Mortgage in installments of the same amount as the value of each of the land rights, which will be charged with the Mortgage, so that later The Mortgage only burdens the remaining Mortgage Object to guarantee the remaining outstanding debt.

The amount of the value of each land right resulting from the split which is encumbered with Mortgage Rights must be agreed upon by the creditor and debtor. The agreement must be made in writing and in detail and signed by both parties as the basis for a partial roya. Thus, in terms of Article 2 paragraph (2) UUHT provides a broad shelter for credit needs with flexible repayment of guarantees.

\subsection{Analysis of Legal Benefits on Partial Roya after the Enactment of the} Regulation of the Minister of Agrarian Affairs and Spatial Planning/Head of the National Land Agency of the Republic of Indonesia No. 5 of 2020 concerning Electronic Integrated Mortgage Services

The theory of legal expediency was put forward by Jeremy Bentham who argued that the state and law existed solely for the true benefit, namely the happiness of the majority of the people. The law must be able to provide the greatest benefit or happiness for as many citizens as possible. The benefits of the law need to be considered because everyone expects benefits in the implementation of the law. Do not let the implementation of the law actually cause public unrest. $^{14}$

The implementation of partial roya on electronic Mortgage after the enactment of PERMEN HT-el has several differences with Conventional Mortgage. Some of these differences include:

\footnotetext{
${ }^{13} \mathrm{Ibid}$.

${ }^{14}$ Keraf, Sonny. (1998). Etika Bisnis Tuntunan dan Relevansinya. Yogyakarta: Kanisius, p. 93-94.
} 
(Garis Horizontal semua-tidak ada garis Vertikal)

Table 1.

Differences in Partial Roya of Electronic Mortgage with Partial Roya of Conventional Mortgage

\section{Partial Roya of Electronic Mortgage Partial Roya of Conventional Mortgage}

The application is made by the The application is made by the creditor through the electronic holder of the Mortgage, the giver Mortgage system. of the Mortgage, and/or the proxy (PPAT).

No need to come to the Semarang You need to come to the City BPN office. Semarang City BPN office to submit files.

No need for a deed of consent Requires a roya consent deed if because the mortgage certificate is the mortgage certificate is lost. in electronic form.

Service time roya only a few Roya service time is about three minutes. weeks.

The benefits of law in the implementation of partial roya after the enactment of the PERMEN HT-el can be seen from the differences mentioned above. Services using technology-based systems that are processed systematically produce timely, efficient, and reliable technology. ${ }^{15}$ The electronic Mortgage System provides more benefits in terms of convenience and time efficiency.

\footnotetext{
${ }^{15}$ Kuspratomo, Yudha Prio., Hasanah, Lailatul Nur., \& Wahyuningsih, Sri Endah., (2019). “Making Implementation Deed Electronically Based on Law of Notary". In Jurnal Akta, Vol. 6, No. 4, December 2019, p. 694.
} 
Applications for partial roya are made by creditors, making it easier for debtors to no longer need to take care of partial roya after paying off their debts. Creditors who have paid off their debts can immediately receive a certificate of title to the land that has been confiscated.

Partial roya applications made with the electronic Mortgage system can be done using computer and internet media, so there is no need to come to the Semarang City BPN office. This can reduce costs or transportation costs in the management of partial roya.

Electronic Mortgage Certificates are easier to store because they are in the form of electronic documents, so there is no need to worry about missing Mortgage Certificates. The roya consent deed is no longer needed because the possibility of loss of electronic mortgage is very small, thereby reducing the cost of making a notarial deed in a partial roya application.

The partial roya process carried out with the electronic Mortgage system takes less time than the partial roya with Conventional Mortgage. This time efficiency is beneficial for land rights holders who wish to transfer land rights.

The weakness to the implementation of partial roya since the enactment of the PERMEN HT-el is that the electronic mortgage system has not been able to accommodate roya services for conventional mortgages. Regarding this weakness, it is necessary to develop an electronic Mortgage system so that it can serve roya against conventional Mortgages.

A partial roya agreement needs to be agreed in the APHT which consists of several objects of Mortgage. The partial roya agreement is needed because in addition to ensuring legal certainty, it also has legal benefits, namely to anticipate if in the future the Semarang City BPN stipulates a policy that must agree on a partial roya in the APHT.

\section{Conclusion}

The authority of the Notary is to make a credit agreement deed with a partial roya agreement and a roya concession deed if the mortgage certificate is lost. The authority of the PPAT is the making and registration of APHT with a partial roya agreement and the submission of a roya application against conventional Mortgage Rights. Notaries/PPATs in carrying out their authority must comply with the provisions and obligations in the applicable legislation to ensure legal certainty. The implementation of partial roya at the Semarang City BPN after the enactment of the Regulation of the Minister of Agrarian Affairs and Spatial 
Planning/Head of the National Land Agency of the Republic of Indonesia No. 5 of 2020 concerning Electronically Integrated Mortgage Services is divided into two, namely conventionally and electronically. Partial roya application for conventional Mortgage can be made by the giver of Mortgage, recipient of Mortgage, owner of land title certificate and can be authorized to PPAT. Applications for partial roya electronic Mortgage can only be made by creditors through a registered electronic Mortgage account. The splitting of certificates of land rights that are encumbered with Mortgage Rights and partial roya on some of the results of the split can be done at the Semarang City National Land Agency on the condition that it must be agreed upon by the creditor and debtor. The implementation of partial roya at BPN Semarang can be done without the need for prior agreement in the APHT. Nevertheless, the partial royalty agreement needs to be included in the APHT to ensure legal certainty and is useful in anticipating if in the future the Semarang City BPN determines a policy that must agree on a partial royalty agreement in the APHT.

\section{References}

Journals:

[1] Deen, Thaufiq., Ong Argo Victoria \& Sumain. (2018). Public Notary Services In Malaysia. JURNAL AKTA: Vol. 5, No. 4, 1017-1026. Retrieved from http://jurnal.unissula.ac.id/index.php/akta/article/view/4135

[2] Kamelia, Mariah., \& Mashdurohatun, Anis. (2017). “Peran Notaris Dalam Pembuatan Akta Perjanjian Kredit Dalam Perspektif Hukum Positif dan Hukum Islam". In Jurnal Akta, Vol. 4, No. 4.

[3] Kinanti, Karenandrie Pradnya., Suharto, R., \& Adhi, Yuli Prasetyo. (2012). "Roya Parsial terhadap Jaminan Hak Tanggungan dalam Praktek di Kantor Pertanahan Kota Semarang". Dalam Diponegoro Law Review, Volume 1 No 4.

[4] Kuspratomo, Yudha Prio., Hasanah, Lailatul Nur., \& Wahyuningsih, Sri Endah., (2019). "Making Implementation Deed Electronically Based on Law of Notary". In Jurnal Akta, Vol. 6, No. 4.

[5] Malik, Djatmika., Limbong, Mangirim., \& Wahyuningsih, Sri Endah. (2018). "Legal Protection for Debtors in Selling Of Immovable Guaranteed Objects Below The Market Price In Indonesian Positive Law". In Jurnal Akta. Vol. 5, No. 2.

[6] Putra, Ida Bagus Jaya Maha., \& Wiryana, I Wayan. (2020). "Roya Parsial Terhadap Hak Tanggungan Bagi Pengembang Yang Menerima Kredit 
Konstruksi Di Bpr Lestari”. In Jurnal IImu Hukum Kertha Semaya, Vol. 8, No. 2.

[7] Valentini, Ni Putu Erna., \& Yogantara, Pande. (2021) "Pencoretan Hak Tanggungan dengan Akta Konsen Roya". In Jurnal Hukum Kenotariatan, Vol. 6. No. 1.

Books:

[1] Adjie, Habib. (2011). Hukum Notaris Indonesia, Tafsir Tematik Terhadap UU No. 30 Tahun 2004 tentang Jabatan Notaris. Bandung: Refika Aditama.

[2] Keraf, Sonny. (1998). Etika Bisnis Tuntunan dan Relevansinya. Yogyakarta: Kanisius.

[3] Marzuki, Peter Mahmud. (2008). Pengantar Ilmu Hukum. Jakarta: Kencana.

[4] Ngadino. (2019). Ketentuan Umum Tata Cara Pembuatan dan Pengisian Akta PPAT. Semarang: Universitas PGRI Semarang Press.

Regulation:

[1] Act No. 5 of 1960 concerning Basic Regulations on Agrarian Principles

[2] Act No. 4 of 1996 concerning Mortgage rights

[3] Act No. 10 of 1998 concerning Banking 